\title{
Erratum: The theology of non-violent Islamic education based on Al-Sira Al-Nabawiyya
}

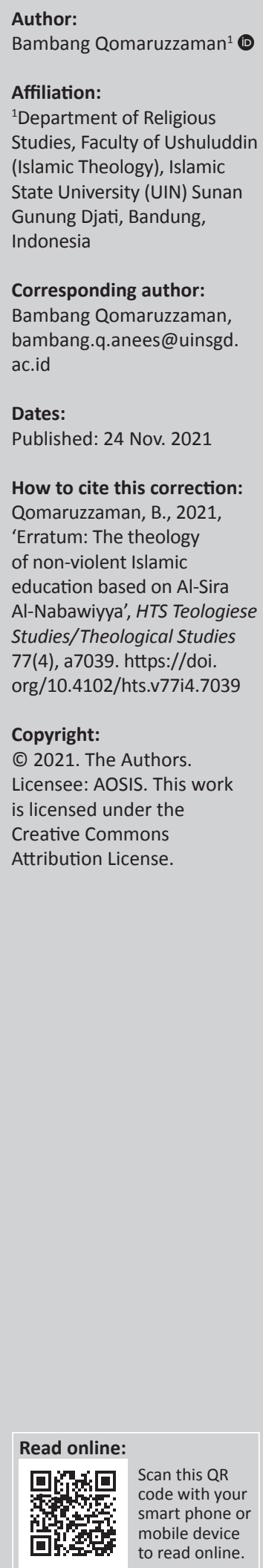

Scan this $Q R$ code with your smart phone or mobile device to read online.

In the version of this article initially published, Qomaruzzaman, B., 2021, 'The theology of nonviolent Islamic education based on Al-Sira Al-Nabawiyya', HTS Teologiese Studies/Theological Studies 77(4), a6268. https:/ / doi.org/10.4102/hts.v77i4.6268, the title of this manuscript contained a spelling error and has been incorrectly published as 'The theology of non-violenct Islamic education based on Al-Sira Al-Nabawiyya'. The correct title is 'The theology of non-violent Islamic education based on Al-Sira Al-Nabawiyya'.

This correction does not alter the study's findings of significance or overall interpretation of the study results. The publisher apologises for any inconvenience caused. 


\section{The theology of non-violenct Islamic education based on Al-Sira Al-Nabawiyya}

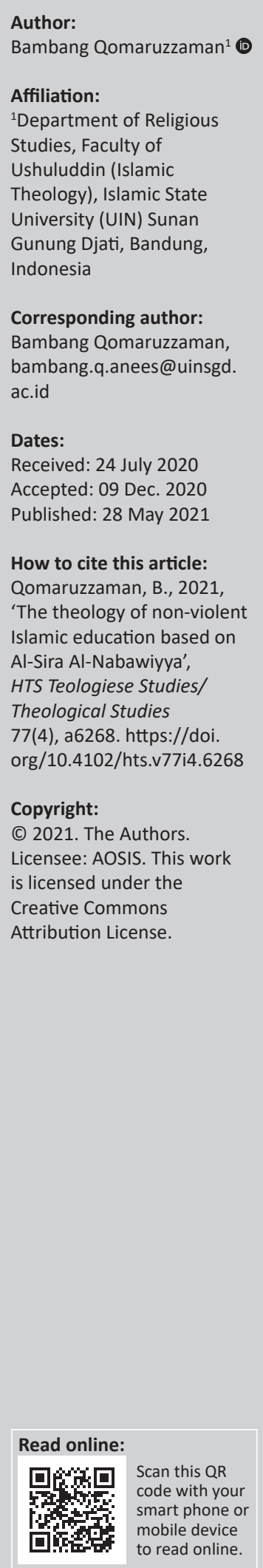

Al-Sira Al-Nabawiyya is often used as a reference to violence in Islam, mainly because war narration is so dominantly displayed. The tendency of using Al-Sira Al-Nabawiyya as the basis of violence conception in Islam drives Islamic teaching practices to become violenceoriented. This article presents a re-reading of Al-Sira Al-Nabawiyya by Wakhiduddin Khan, Tariq Ramadan and Satha-Anand, with a mimetic anthropology framework. The reading on Al-Sira resulted in three conclusions. Firstly, there are many non-violence stories at all stages in the life of Prophet Muhammad, since the pre-prophetic era until his death. Secondly, the Prophet Muhammad was a teacher who based his activities on the principles of tawhîd, patience, love, forgiveness and appreciation for humanity. Thirdly, educational activities are Muhammad's exemplary activities which are full of non-violent values. The findings of this article can be used as the basis for the reformulation of Al-Sira Al-Nabawiyya teaching materials in Islamic Education as well as the basis of teaching activities for Islamic teachers.

Contribution: This article contributes to a paradigm shift in teaching the History of the Prophet Muhammad in a peaceful Islamic education system. The peaceful paradigm in this article can also divert the tendency of Islamic extremism to become an Islam that provides peace and prosperity to the universe (rahmatan lil 'alamin).

Keywords: theology of non-violence; Islamic education; Al-Sira Al-Nabawiyya; theology; education; history.

\section{Introduction}

Education is an essential means to provide children with the knowledge, skills and competencies needed to maintain harmonious relationships with different people. Education in Indonesia has been interrupted when it is alleged that there is a tendency for religious teachers, prospective teachers, spiritual activist students and students in general to have an intolerance understanding that is susceptible to violent extremism (Azca 2013; Burhanuddin 2016; Fuad 2020; Muhammad \& Pribadi 2013; PPIM UIN Syarif Hidayatullah Jakarta 2017, 2018). The phenomenon of education as a driver of radicalism is also found in Pakistan (Mohanty \& Mahanty 2010). Despite the fact that no relation has been found with the escalating violence in the name of religion since the late 2000s, the findings of this survey are quite alarming and demand the search for long-term solutions. One of the solutions put forward by this article is by presenting Al-Sira Al-Nabawiyya in a non-violent perspective.

There are a number of articles in the education field which counter the tendency for intolerance; the proposed solution is only limited to analysis of curriculum content (Kaymakcan 2007; Nurwanto \& Cusack 2017), student diversity (Afrianty 2012), multicultural perspectives (Baidhawy 2007; Purwakania Hasan \& Suwarni 2012), instructional textbooks and holistic management (Raihani 2011). This article argues that tolerance education must be approached from the source of action and teaching material, namely, the theology of non-violence. This is based on the fact that the perpetrators of violence believe that their actions are religious orders (Samudra 2005), for example, based on the verses of the Qur'an (Qur'an, 2:191), 'then kill them (infidels) wherever you meet'.

The reference to the jihad verses results in a conclusion that jihad means 'fighting only, fighting with the sword' (Emerson 2003) which must be done anytime anywhere as it is obligatory to do fasting. This shows that jihad is presented not only as a discourse but has been wrapped theologically. Not only that jihad is positioned as fard al-kifayah which must be carried out even though through representation (Habeck 2006):

[T] hat faith is obliged to defend the territory of Islam when enemies invaded it ... [an obligation] first and foremost on the Muslims that were attacked, but if they were too weak to mount an effective defense, the obligation was gradually increased to include the entire Islamic community (Kippenberg 2011). 
The perpetrators of violence that disrupt the stability of a State also underlie their actions to reject a democratic state based on the belief that only God can govern the world and provide a basis for a regulated society (Schwarzmantel 2011), while the government system regulated by other than God must be destroyed. For fundamentalists Jihadists such as Hizb al-Tahrir and al-Qaeda, criticism of democracy is the basis of their ideology, and they argue that 'adopting Western laws and democratic rules are so evil that even if laws identical to those of the shari'a [Islamic law] were adopted in a democratic system would make them wrong and kufr [referring to unbelief or acceptance of false ideas]'. (p. 73)

At this point, referring to Mark Juergensmeyer (2003), religion has been used as a tool of violence, in the form of making violence a theology. On that basis, the counter-discourse on this phenomenon must also play in the same area, in the theological area. This is perhaps what Sachedina meant that '21st-century Islamic theology must communicate beyond the language of certain traditions' (Sachedina 2000), namely, pluralism that can bring peace and justice to contemporary society (Sachedina 2000), or non-violence based on Islamic teachings (Darmalaksana et al. 1990; Easwaran 1984; Karim 1998; Pal 2017). In this way, the Islamic community can 'play a role as a pioneer in the development of non-violence, and there is every reason that some of them do indeed have to lead the development of non-violence' (Burns 1996).

In contrast, the existing discourse on non-violence or multicultural Islam, this article makes Al-Sira Al-Nabawiyya as the core values of the theology of education. There are two fundamental reasons for the choice of Al-Sira Al-Nabawiyya as the basis of the theology of non-violence. Firstly, violent jihadists referred their behaviour to a number of wars carried out by the Prophet. Presenting the perspective of nonviolence to Al-Sira Al-Nabawiyya would cut off the violent jihad source of reference. Secondly, the life and actions that the Prophet reflected on the divine message revealed through him became an action reference for all Muslims. Imam al-Ghazali (1058-1111), one of the greatest theologians and Islamic philosophers, wrote that Prophet's character was the Qur'an (Al-Ghazali n.d.:260). This is why the Qur'an states: 'Indeed, in the Messenger of Allah (Muhammad) there is a pattern of a good example for you' (Qur'an 33:21). His life is a universal example for Muslims throughout the world, so this article can provide behavioural changes from violence to non-violence when it can show historical evidence that the Prophet was a non-violence figure.

History has a very strategic position in Muslim education. Historical teaching encourages students to participate in history (Kuntowijoyo 1991); therefore, history does not only tell the past but what has been thought, said, done, felt and experienced by humans (Kuntowijoyo 1994). Historical teaching is recognised as the main site for building identity, transmitting collective memory and forming 'imagined communities' (Anderson 1991). History gives young people narratives about themselves, others and nations, and it signals them what is important to know about their past. Moreover, there are studies that highlight ways that certain historical education can contribute to violent conflict, for example, by strengthening sectarian identity, offering negative images and stereotypes from 'the other' and naturalising victims or the superiority of certain groups (Davies 2004).

History education has an important function in humanities education. Smith and Vaux (2003) identify that history education is needed in the process of reconciliation by addressing the legacies of conflict'. It is needed in communities divided by 'identity politics' and experiencing violence and human rights violations in 'multiple levels and types of healing and reconciliation and to move forward must come to terms with the past' (Chapman 2007) which is obtained through history education. Sartono Kartodirdjo revealed that if history is to remain functioning in education, it must be able to adjust to the current social situation (Sartono 1990).

The Indonesian National Education System emphasises the importance of historical education of Islamic Culture. In public schools, Islamic Cultures History is one of the teaching materials from Islamic Education Subjects. Whilst in madrasah (Ibtiadiyah, Tsanawiyah and Aliyah), Islamic Culture History is an independent subject. There are three functions outlined in the Islamic Culture History subjects listed in the madrasah curriculum, namely, educative, academic and transformative (Departemen Agama RI 2004). Islamic Cultures History is taught with four objectives: (1) providing knowledge about the History of Islam and Islamic culture during the time of the Prophet Muhammad and Khulafâ' alRâsyidîn to students so that he has an objective and systematic concept from a historical perspective; (2) taking wisdom, values and meanings contained in history; (3) instilling appreciation and strong will to practise good morals and stay away from bad morals based on careful historical facts; and (4) equip students to develop their personalities based on exemplary figures so that a noble personality is formed (Departemen Agama RI 2004).

The acquisition of wisdom through history makes history education a way for students to get the spirit of the past to understand the present and the future. Unfortunately, the History of Islamic Culture was written (and later taught) as a history of warfare (Waqidi 2012; Watt 1990). This can affect the reader because reading someone will build perceptions in him. Mistaken perceptions of the subjects of warfare can have fatal consequences for the mindset and actions of students, which at the end can lead to radicalism in religion. Errors in the meaning of war in Islamic civilisation are compounded by the many Islamic history books written by the West, such as Islam and the West: A Historical Cultural Survey (1984), History of the Arabs (2008) and so forth. Medieval Christian writers described Muslim soldiers with swords in one hand and Al Quran in the other (Ahmed 2003). Islam is called the sword religion, a belief that leaves true spirituality by purifying violence and knowing no tolerance (Armstrong 2011). 
However, there is a lot of literature that has written the biography of the Prophet Muhammad in various perspectives, such as physicians, diplomats, generals (Ghiloni 2016) and also as an educator (Gade 2010; Ghuddah 2003; Untung 2005). All Al-Sira Al-Nabawiyya writers put the prophet as a 'sublime life' (Haykal 1976) 'genius' (Al-Aqqad 1942; Ali 2014), 'distinguished, exalted personality' (Gulen 2010) and 'too full of truth to deceive and too full of wisdom to be self-deceived' (Lings 1983). Although there is no biography of Muhammad that uses the perspective of non-violence specifically, at least two writers of Al-Sira Al-Nabawiyya who have an orientation to describe the Prophet as a peaceful figure are Ramadan (2007) and Wahiduddin Khan (1998). There are also Satha-Anand (2015) and Nimer (2003) who made the historical fragments of the Prophet as an exemplary model of non-violence.

Whilst recognising the importance of curriculum, textbooks and holistic cultural policies, this article argues that Islamic theology of education and Islamic history subject matter is needed to be reformulated. This means that Islamic education programs and research must be directed towards having a spirit of non-violence, not just a discourse. The theology of education in this article includes the motivation and attitudes of the teacher in his profession, goals and at the same time the subject matters of Islamic history education, all of which contribute to the promotion and maintenance of the spirit of non-violence in the school community.

In supporting this argument, this article is organised as follows. First of all, this article will present a brief description of the reading of the mimetic anthropology of Al-Sira Al-Nabawiyya on the life history material of the Prophet Muhammad which is commonly used in Islamic religious education. There are two materials about the life history of the Prophet Muhammad which is the focus of this article: firstly, the life span in Mecca (pre- and post-prophetic) and the life span in Medina; and secondly, the history of war by the Prophet Muhammad. Then the results of the reading of this mimetic anthropology are discussed in the perspective of non-violence for Islamic education theology.

The core of this article presents a system component of non-violence theology for the promotion and maintenance of tolerance education through the historical reconstruction of the Prophet Muhammad. As much as possible, the article provides a special reference for education in Indonesia. In short, this theoretical article proposes an Al-Sira Al-Nabawiyyabased tolerance education for schools in Indonesia.

In this article, the entire history of the Prophet Muhammad will be read in the framework of mimetic anthropology. Mimetic and tawhid anthropology is the idea of Adam Ericksen in The Universal Truths of Islam and Mimetic Anthropology: The Tawhid of God and the Tawhid of Being Human (Ericksen 2009), which orientates the principle of tawhid as a method of interpreting non-violence against the Qur'an. In this article, Ericksen uses the mimetic theory of Rene Girard, the concept of tawhid (Ramadan 2005) of Tariq Ramadan and the theory of Naskh [Abrogation] in the tradition of Qur'an interpretation.

Firstly, the mimetic desire and the mechanism of the scapegoat are related to the devil (Girard 2001), and trust in God emancipates victims. Then, by quoting Girard's book, The Scapegoat, Ericksen emphasised the 'the mythical cover-up of violence' (Girard 1986) whilst the scriptures say, criticise and encourage resistance to violence. From the two theories, Ericksen claims that faith is someone's belief that God does not want to create victims, but that is God 'sides with victims, with scapegoats' (Aguilar Ramírez \& De Beer 2020; Williams 1996) of culture.

Secondly, Ericksen referred to the Ramadan writings that the core and purpose of Islamic teachings are 'adalah and maslahah, recognition of the One ... and of al-maslahah - in the sense of the common good and interest of humankind and the universe' (Ramadan 2008). Ramadan also stated that 'Faith in God and knowledge, in light of the divine, must have as their immediate consequences a behavior, a way of acting that respects an ethic and promotes good' (Ramadan 2009). From these two things, Ericksen concludes two tawhid in Islam, namely, tawhid which refers to all aspects of life in the One God, and tawhid of humanity which is the orientation of benefit (maslaha) as the only human action. The tawhid principle asserts that the meaning of all aspects of life must be referred to God and there will be no conflict in God. Ericksen (2009) further stated:

[I]f God is the Lord and Giver of Mercy and the Source of Peace, then tawhid means that nothing within God can conflict with Mercy and Peace. To locate conflict, rivalry and violence with or within God is to break the fundamental theological concept of tawhid. (Ericksen 2009:6)

Thirdly, the concept of naskh is a way of interpreting the Qur'an that allows the cancellation of one verse with another verse. Ericksen, by referring to the tawhid principle that all must refer to the oneness of God, explores further the concept of naskh that 'the entire verse of the Qur'an must be cancelled by [or interpreted through] the Unity of God'. The verse about the oneness of God that can cancel all verses of the Qur'an is 'basmallah'. Basmallah for Ericksen becomes 'the lens that the Qur'an provides to use when interpreting the Book of the Qur'an and the Book of the Universe' (Ericksen 2009). Basmalah expresses the ultimate desire of God to offer love and mercy as well as the desire of God so that humans organise their lives based on love.

On the basis of these three assumptions, Ericksen then interpreted all the verses of violence in the Qur'an as a call for peace. The many verses that command war or kill in the Qur'an, for Ericksen, show that the Qur'an is not a culture or myth that hides violence. In other words, the Qur'an suggests violence to be criticised so that it is not carried out whilst promoting peace. The violent orientation of the interpreters of the Qur'an to mimetic anthropology comes from the desire of the human mimesis of its oppressors, whilst the principle 
of tawhid constantly calls on humans to only imitate the God of the most Rahmân and Rahîm.

\section{Sirah Nabawiya in mimetic anthropology perspective}

This section discusses two aspects of the Sirah Nabawiya which are often used as references in Islamic education preprojects. First, the life history of Prophet Muhammad SAW (Pre-prophetic history when rebuilding the Ka'bah, Postprophetic Mecca, and the Life of the Prophet (SAW) in Medina). Second, the story of the Prophet in battle which is usually used as a reference for violent extremism in Islam. These two aspects are read using mimetic anthropology.

\section{Al-Sira Al-Nabawiyya as the source of non-violenct Islam}

Ericksen's mimetic anthropology believes that Islam does not encourage violence; it encourages the spread of mercy to all lives. Ericksen pointed out that even in the three verses of Surah Al-Baqarah which are often used as a basis for fighting for fundamentalists, they showed a non-violent orientation. One of the verses referred to by Erickson states that 'fight for God against those who oppose you, but do not overreach: God does not love those who transgress' (Qur'an, 2:190). This verse, on the one hand, expresses violence, but emphasises non-violence, namely, 'not exceeding limits'. This verse also shows the nature of God as well as the desire of God so that humans have the same traits as him, namely, dislike violence.

On the basis of the mimetic anthropological framework, the whole Al-Sira Al-Nabawiyya is the story of a Prophet who was guided to avoid violence. There are two ways to read that can be used from Ericksen's mimetic anthropology, namely, naskh theory with tawhid and religious theory as opponents of violence. Firstly, if the way the Qur'an is interpreted with a basmallah lens ['In the name of God, Most Gracious, Most Merciful'], then the entire history of the Prophet Muhammad is interpreted under the lens of the verse 'We did not send you (Muhammad) except as compassion for all nature' (Quran, 21:107). All of the behaviour of the Prophet Muhammad, even when fighting, must be constructed as an effort to spread the mercy to the whole universe.

Wahiduddin Khan is one of the authors of Al-Sira Al-Nabawiyya who believes that the Prophet Muhammad was a figure of non-violence. 'The position of peace in Islam is so sacred, whereas war in Islam is only permitted under extraordinary circumstances if it cannot be avoided' (Khan 2002), Wahiduddin Khan wrote. In the book The True Jihad, The Concept of Peace, Tolerance and Non-Violence, which was written on the occasion of September 11, Khan asserted that the main purpose of Islam was to spread faith faithfully (Khan 2002), whilst sociopolitical renewal is a secondary agenda that will be achieved by itself through Muslim spiritual renewal (Afsarudin 2018).
Khan then sorted out the moment of life of the Prophet who showed the attitude of non-violence, namely, the Mecca Period, Migrated to Medina, Khandaq War, Hudaybiya Treaty and the Liberation of Mecca. For Khan, these five historical moments show that the position of peace in Islam is so sacred, while the violence of war in Islam is only allowed in extraordinary circumstances if it cannot be avoided' (Omar 1999). These five moments will be the framework of the discussion of this article, plus one moment at the Medina phase when the Prophet received a visit from Najran Christian Priests (Considine 2016).

\section{Pre-Prophetic history: Rebuilding the Kaaba}

The Prophet Muhammad was born in the midst of the Jahiliyah society, namely, people who 'forget the more human aspects', 'instead of protecting weaker members, some families continue to push forward and become richer, while others get poorer' (Armstrong 2012). The Jahiliyyah society is also described as an aggressive society that can make violence a way to solve problems (Armstrong 2012).

The Prophet Muhammad received revelations that replaced the aggressive ethos of ignorance, with the ethics of hilm [forgiveness], namely, the attitude of patience, steadfastness and forgiveness; instead of spilling their wrath, they will remain calm even in palling annoying situations; they did not hit back when they were harmed, but gave up their vengeance to God (Izutsu 2002). Those who practise hilm love the poor, disadvantaged people, orphans and widows, feed the poor even when they are hungry themselves (Armstrong 2012).

This hilm behaviour was apparently possessed by Muhammad before he was sent as a Prophet. This can be seen in the event of a dispute over the laying of the Aswad stone amongst tribal chiefs. The incident occurred in 605 when the Prophet Muhammad was 35 years old (before being sent to be a Prophet and preacher). This event tells of the Quraysh tribal chief's dispute about who put the black stone in the corner of the Kaaba. Every clan wants the honour of lifting the stone and putting it in its place; the debate is quite tense and lasts for 4 or 5 days until each clan prepares to fight to resolve the conflict. Then, the eldest of the people present suggested to the warring groups that they follow what was suggested by the first person who entered the Kaaba compound through the gate of 'Bab al-Safa'. All parties agreed on this proposal and the first person to enter through the gate was Muhammad.

After listening to the case, Muhammad asked them to bring him a robe, which he then spread on the ground. He took the black stone and placed it in the middle of the cloth. Then, he said, 'Let each clan hold the edge of the robe. Then, you lift it together'. When they lifted it to the right height, Muhammad took the stone and placed it in a corner. And the rebuilding of the Kaaba was continued to completion (Lings 1983). 


\section{Ramadan (2007) called this event:}

[S]howing that in addition to the quality of the heart and its moral privileges, Muhammad also had the sharpness of intelligence used to devote to respect and peace between humans and various tribes. (p. 59)

Satha Anand (2015) stated that this event occurred when he did not have any political power, only as a citizen of the city of Mecca, but had become a peace-maker. There are four important values raised by the Prophet on this event, namely, patience, appreciation for the humanity of all parties, sharing together and creativity in solving problems. The patience of the Prophet was shown by his willingness and ability to hear problems that showed the will to learn all the information he got. Appreciation for the humanity of all parties was realised when involving all the conflicting groups to lift the black stone. In addition, the value of creative thinking characterised by the innovative use of robes as a vehicle for resolving the conflict must also be emphasised.

Ramadan (2007) concluded that in the process of establishing peace, Muhammad always:

[T]aught the heart not to let him be defeated by emotions and arrogant thoughts; lead the mind towards a solution that calms the heart so that it allows one to control himself with full tenderness and wisdom. (pp. 60-81)

\section{Post-Prophetic Mecca}

Whilst in Mecca (610-622 AD), the Prophet encouraged his followers to behave patiently. This situation for Khan (1998) was the main source of inspiration for the attitude of non-violence:

There were many problems in Mecca at the time which could trigger conflicts and clashes. But, by avoiding such problems, the Prophet explicitly restricted his field to the peaceful spread of God's words. (p. 5)

The Prophet (PBUH) did not show a tendency to exert power in any form, even in self-defence. The Prophet practised nonviolent resistance reflected in all his teachings in that period when Muslims were a minority and under threat. The teachings of the Prophet centred on the values of patience and fortitude in the face of oppression. Even though he was tortured, slandered, insulted and exiled, the Prophet did not allow himself to use violence and profanity. On the contrary, the Prophet's teachings centred on faith and hope for enlightenment and peace.

Khan put forward two stories of the Prophet's determination to remain patient. Firstly, when the Prophet gathered 38 of his followers, Abu Bakar felt that he had an urgent support to openly preach, the Prophet refused. Secondly, in the 6th year of da'wah in Madina, Umar protested to the Prophet, 'Why should we keep Islam a secret if what we are doing is right, while those who are wrong are free to broadcast their beliefs'? The Prophet also refused (Khan 1998).
There are two other events that get the attention of the Sirah writers, namely, the spread of Islam in Ta'if and the boycott event. The Thaif event was an event described by the writers as a critical event; the Prophet was rejected, insulted, stoned and even chased by the residents of Ta'if. The Prophet did not condemn the treatment of his opponents; even when there was an opportunity to give a reply, the Prophet said, 'Don't. Who knows God will issue someone who says, "there is no god but Allah from their womb"' (Ramadan 2007).

The boycott was the culmination of the Quraysh's pressure on the Prophet Muhammad and his followers; at that time, everyone was threatened not to trade and help the Muslims. Against this pressure, the Prophet chose to remain silent, not resist, allowing the boycott to take place until finally there was an awareness to stop the boycott. Regarding the events of the boycott of the Prophet, Khan stated, 'the silence of these people while accepting the abusive treatment of their enemies has resulted in guilt in the heart of the enemy' (Khan 1998).

The migration of the Prophet Muhammad to Medina was specifically seen as a strategic non-violent action (Nimer 2003), which enabled the Prophet to build a strong Islamic centre. The migration from Mecca to Medina is an example of the Prophet's patience. When the Quraysh decided to kill Prophet Muhammad, he had two choices: pull out the sword and fight to defend and or leave Mecca, looking for a safer place to stay temporarily. But the Prophet chose the second path, 'He calmly thought about the situation faced and decided to move to Medina, where he could continue the same task' (Khan 1998).

\section{The Prophet Muhammad in Medina}

Ramadan (2005) described the episode of the Prophet arrival in Medina with peace message at Quba:

[S]pread peace [salam], feed the hungers, respect family relation, pray when people asleep, so you will enter the haven of peace [dâr al-salâm], this is the primary message that becomes a responsibility of a Muslim. (p. 158)

This message of peace is the spirit of the two most important events that took place in Medina, the Medina Charter and the agreement between Prophet Muhammad and the Christians of Najran. The two of them are considered as the notable moments conceiving Prophet Muhammad as a non-violent figure.

The Medina Charter is an important event that shows the peaceful orientation of Prophet Muhammad in resolving the conflict between the Medina Arabs and the Jewish people. Instead of mobilising the masses to drive away the Jewish who had been the source of problems for the Medina residents, the Prophet (PBUH) invited them into an agreement. It is affirmed in the Charter that both for the 
native of Medina and the Jewish people 'have the same rights and obligation as ours' (lahum mâ lanâ wa 'alaykum mâ 'alaynâ) (Ramadan 2005). It is also said in the Charter that all of them belong to the same umma and get equal protection.

The Prophet Muhammad's and Christian of Najran agreement received significant attention lately after the release of two books written by John Andrew Morrow: The Covenant of the Prophet Muhammad with the Christians of the World (Angelic Press 2013) and The Covenant of the Prophet Muhammad with the Christian of his Time: The Primary Documents (Covenants Press 2013; Considine 2016). It was stated in the two manuscripts that the Prophet Muhammad ordered the Muslims not to attack the peaceful Christian community and even ordered that they not undergo the construction of churches (Considine 2016). Beyond the controversy over the findings of this treaty document, Ibn Ishaq (1987) actually discussed Muhammad's tolerance and friendliness towards the visitors of Najran Christian:

When they came to Medina, they came into the Messenger's mosque as he prayed the afternoon prayer clad in Yamani garments, cloaks and mantles, with the elegance of men of B. al-Harith b. Ka'b. The Prophet's Companions who saw them that day said that they never saw they are like in any deputation that came afterward. The time of their prayers having come, they stood and prayed in the Messenger's mosques, and he said that they were to be left to do so. They prayed towards the east. (p. 271)

The events of the Najran Christian visit took place around 631 AD after the Prophet Muhammad sent a letter to several Christian communities around Medina to embrace Islam. The Najran Christian then sent a delegation (of 60 people) to Medina. After that, there was a diplomatic dialogue between the Prophet Muhammad and the Christians of Najran. Ibn Hisham said that the contents of the talk revolved around confirming the teachings that the Prophet Muhammad brought about Najran's Christian beliefs and Isa's status in Islam (Hisham 2002:112). When it was the time for them to pray, the Najran asked permission. As there was no nearby church, the Christian delegation began walking out to pray on the streets of Medina. The Prophet Muhammad then told them, 'You are followers of God. Please pray in my mosque. As a human, we are all brothers' (Considine 2018). When the Najrans left Medina, a Najran leader said to the Prophet, '... we decided to leave you as you are and you leave us as we are. However, send with us a man who can act as our guardian judge'. 'The Christian group left Medina with a written message that the Prophet would protect their lives, property, and human rights such as freedom of conscience and religious freedom' (Considine 2018).

For this event, Ramadan (2009) commented:

$[T]$ he early apostles will never forget the actions of the Prophet. They can draw a lesson from it about the respect that Islam requires from the believers, who are called upon to be more than just tolerant, to learn to hear and acknowledge the honor of others. ... more than just tolerance (which undermines the great nature of arrogance in a power relation) the respect of others who are commanded by God is based on mutual relations that are egalitarian. (p. 204)

\section{The story of the Prophet Muhammad in battles}

The battles fought by the Prophet after he resides in Medina often become the fundamentalists' reference to do violent jihad. Khan (2002) emphasised that:

[T] here was no slight intention in the hearts of the Prophet disciples to concur a land or to pile up spoils of war. They prefer to become the source of true faith richness for others. (p. 164)

Kahn's (2002) judgment was based on the message of the Prophet to Ali Ibn Abi Talib in the war of Khandaq:

If you arrive in the valley, invite them to enter Islam and explain their responsibilities to God. For God's sake, if there is one person who gets the demands of Allah Subhânahu wa ta'âla to become a follower of Islam through you, then that is far more good for you than if you got a flock of red camels. (p. 165)

Khan (2002) also put forward another example of the Prophet's war behaviour during the Hunayn War:

The Prophet had the opportunity to take revenge on Thaqif's ally Hawazin. But the actions he took were just the opposite. He received a group of representatives of the hawazin tribe who requested that the Prophet release six thousand prisoners of war. His treatment of them is very friendly. He not only freed his prisoners of war but also gave them the clothes and supplies they needed on the trip. (p. 156)

Al-Ghazali related that one day someone put his sword on the Prophet's head and asked who would protect him. The Prophet Muhammad replied: 'Lord'. The sword fell from the man's hand and the Prophet picked it up. He then invited the person to testify that there was no god but Allah and that Muhammad was his messenger. The person said: 'I am not jealous of you, I will not kill you. I will not follow you and I will not join the people who are fighting you'. The Prophet then released him (Al-Ghazali n.d.:271). In another case, a Jewish woman mixed poison into the Prophet's food at Khaibar. When the woman was caught, she said: 'I intend to kill you'. The Prophet replied: 'God will not give you the power to do that'. The companions of the Prophet then sought the Prophet's approval to kill the woman. The Prophet, once again, forgave her and replied, 'Don't kill her' (Al-Ghazali n.d.:271).

The war carried out by the Prophet was based on the command of the Qur'an (QS. 2:190) on condition that it does not 'exceed the limits'. This also underlies the decision of the Prophet Muhammad during the Hudaybiyyah incident. In the 6th year after Hijrah, the Prophet decided to invite his companions to Umrah to Mecca. About a thousand people took part in the trip without carrying weapons. The Quraysh obstructed the Prophet's desire to go to Umrah peacefully. The situation heated up when the Quraysh continued to block the Umrah congregation until finally a peace agreement 
(Treaty of Hudaybiyyah) was made which was considered by some friends to be very detrimental to the Islamic ummah.

Regarding the Hudaybiyyah incident, Armstrong (2011) wrote:

Tragically, Muhammad found that war had its own deadly dynamics, in a hard battle, cruelty was committed by both parties. So, as soon as the flow turned around favorably, Muhammad adopted a policy of peace, riding without armed with a thousand unarmed Muslims into enemy territory. There, after almost being massacred by the Meccan cavalry, he negotiated an agreement with the Quraysh, accepting the conditions that angry followers seemed to throw away all the profits they had earned. (p. 70)

Whilst Khan stated Afsarudin 2018:

Ideally peace must be accompanied by justice. But ... peace can be realized first even though he is still lacking in terms of justice, as exemplified by the Prophet Muhammad's agreement to the Hudaybiyyah Treaty, which did not benefit Muslims. However, acceptance of this unequal peace agreement encourages justice and makes war unnecessary. (p. 362)

Examples of non-violent movements were also seen one year after the Hudaybiyyah agreement. After many followers of the Prophet were persecuted, some were tortured and killed (Lings 1983). When the Prophet entered Mecca with 10000 people returning to Mecca and the Meccans, who made mistakes against Muslims in earlier times, afraid of their revenge, the Prophet chose the path of peace. The Prophet Muhammad stated:

Indeed I say as my brother Yusuf said: On this day there is no reproach (that is inflicted) upon you: God will forgive you, and He is the most merciful among the merciful. Al-Quran, 12:92 (Lings 1983:79-80)

This example of non-violent behaviour is reinforced by a farewell sermon which is the Prophet's last important message for the Islamic ummah. In that last message, the Prophet Muhammad stated that the period of ignorance had ended, so too with all its practices, hostilities and conflicts based on power and material benefits. Since then Muslims have been united by faith, brotherhood and love, therefore in any condition, the Muslim community cannot 'persecute or be persecuted' (Ramadan 2005). The Muslim Ummah is asked to learn to understand the equality of all human beings before God, 'The best in the eyes of God is the most fearful. Arabs are not superior to non-Arabs, tired of their strong awareness of God' (Ramadan 2005).

\section{Al-Sira Al-Nabawiyya as the basis of the non-violent education theology}

The description of Al-Sira Al-Nabawiyya above uses the perspective of non-violence on the behaviour of the Prophet in the whole history of his life. The whole history shows a peaceful orientation, full of patience in the face of agitation and aggression and forgiveness. To formulate Al-Sira
Al-Nabawiyya as the basis for the formulation of the non-violent education theology, this discussion will be directed at two aspects, namely, the value of Al-Sira Al-Nabawiyya for the formulation of non-violent theology and for the formulation of the teaching of non-violent teachers.

\section{Non-violent core values of Al-Sira Al-Nabawiyya}

The whole story of the Prophet shows compassion, forgiveness, respect for humanity and patience. Several verses in the Qur'an clearly indicate the divine purpose of the Prophet Muhammad existence as 'mercy (rahmah) for any of you who believes' (Qur'an, 9:61). As God's mercy is not selective, it is this universal compassion that permeates the existence of the Prophet. The whole action of the Prophet Muhammad is a manifestation of this value of mercy. Therefore, for example, there were no wars which were carried out for the purpose of revenge; all wars were carried out to deliver peaceful messages.

Equivalent to mercy (rahmah), Karen Armstrong (2012) mentions the value of hilm [forgiveness]. This hilm value is described as creating behaviour:

$[P]$ atient, steadfast and forgiving, instead of spilling their wrath to remain calm even in the most annoying situations; they did not retaliate when they were harmed but gave up their vengeance to God. (p. 68)

It is from this hilm value, Armstrong concludes, that Islam is not a pacifist religion.

In line with Armstrong, Satha-Anand (2015) believes that from this value of mercy, another value arises. From this compassion, the will to be patient appears. Compassion also facilitates the act of appreciating the humanity of others who, in turn, will be propitious to share together. Without compassion, the cessation of hatred cultivated by the bitter memories of the past will be difficult and, therefore, forgiveness becomes almost impossible. This compassion can also encourage the emergence of creativity that is conducive to peace.

There are two main values that deserve primary attention, namely, patience and forgiveness. Patience is one of the meanings of jihad (Afsarudin 2018). Those who are patient, according to Khan, are people who do not allow a problem to influence him, someone who has never exhausted his enthusiasm in achieving his ultimate goal. ... not broken to face the pressure of any size, those who stand up without compromise, do not care how much the challenge must be faced (Khan 1998). Patience takes part, helping them not to give up just because they feel that their words are not heeded by others. Patience is the fruit of tawhid when someone trusts God wholeheartedly, and then no one is able to disturb that person's determination. 
Patience as the basis of the value of non-violence was put forward by Khan (1998) in the statement:

If we already understand the value of patience, we do not immediately repay oppression against us. Instead, we will consider further ahead and begin to devise steps that will lead us to the peak of success. (p. 169)

Elsewhere, Khan (1998) wrote, 'Patience makes someone emotional and produces violence, while patience makes the power of the soul, namely the mind, grow within us'.

The pattern of behaviour of the Prophet is filled with core values of forgiveness. The value of forgiveness is mentioned in the Koran as an obligation of Muslims, even when they are angry (Departemen Agama RI 2015). The Qur'an asserts that forgiveness and reconciliation are appropriate actions in a conflict situation. Forgiveness is the second core value after being patient, through forgiving past, irreversible actions that can be offered (MullerFahrenholz 1990), forgiveness becomes an act of mutual liberation for those who forgive and who are forgiven. It also helps change social relations, so that peace is possible in the future.

\section{Compassion as the key of non-violent teacher theology}

Non-violent values that can be drawn from Al-Sira Al-Nabawiyya are patience, respect for humanity, sharing, creativity, love for others and forgiveness. The whole values are a manifestation of tawhîd embedded in the Prophet Muhammad mission. Hence, teachers need to place the values in the teleological meaning of their existence so that their actions always spring from the Prophet's example.

Prophet Muhammad (PBUH) is also always conceived as an educator who made education actions as his main activities. Tibawi (1954) stated that 'both as a preacher of a new religion and as the head of a state, Muhammad proved to be an effective teacher and an enthusiastic promoter of learning'. As an educator, Prophet Muhammad showed his success. Saqeb (1996) (Muller-Fahrenholz 1990) pointed out that in the beginning, there were only 17 educated Muslims in Mecca and most of the teachings were delivered orally. However, this number changed dramatically at the time of his death (Azami 1992). In Medina, Muhammad promoted mass education resulting around 600 students in a short time (Azami 1992).

Moreover, Prophet Muhammad addressed himself as a teacher, 'I was sent as a teacher' (Al-Qazwini 1993). This statement was manifested in the educational activities he did, he chose to sit with students, motivate Muslims to learn and teach knowledge, guiding the attitudes of their followers painstakingly. He laid down the basic principle by stating: let the poor and the rich be equal before you in the acquisition of knowledge (Totah 1926). Later, he promised various gifts: he, who spoke of knowledge, praises God; he, who dispenses instruction in it, bestows alms and he, who imparts it to its fitting individuals, performs an act of devotion to God (Gulick 1953). After being considered masterful, students are given the responsibility to convey to others, 'Return to your family and teach them (religious knowledge) and tell them (to do good deeds) and pray as you see when I offer my prayers ...' (Haykal 1989).

Al-Sira Al-Nabawiyya describes the Prophet's first madrasa taking place in many places in mosques and homes. He appointed teachers to teach reading and writing in nine mosques around Medina that were also served as schools at the same time (Wan Daud 1989). In addition, the famous one is the porch of the Medina mosque called al-suffah. This place is dedicated to lodging for outsiders and poor people. This is where poor people learn to read, write, Islamic law, memorise al-Qu'ran and the method of reading al-Qu'ran correctly directly under the direct supervision of Muhammad (Hamidullah 1939). There were also other lessons such as swimming, shooting arrows, basic mathematics, basic medicine, astronomy, genealogy and phonetics. Therefore, Al-suffah is the first institution consisting of teachers, students, counselors, classrooms and student homes.

The Suffah tenants were mostly composed of unmarried young men, the poor and orphans (Watt 2012). Their misery is depicted in the hadith narrated by Abu Hurairah, one of the young men who studied there, 'I saw seventy Suffah people and none of them had robes' (Ghiloni 2016). The atmosphere of learning in Suffah was so interesting as Abu Darda stated (Al Ghazali 1962):

I would rather learn one point than spend my night in continual prayer. ... Be a learned, or a learner, or an auditor but never anything else ... (p. 12)

The following description of Suffah is presented by Atay (2007):

Since they neither had a family to feed for [sic] nor any other worldly worries to look after, such as camel flocks or beautiful date gardens, their sole business was either to sit next to the knee of the Prophet to gather the treasures he was distributing day by day or keep themselves busy with praying or spiritual cleansing. (p. 462)

Another point to consider in the process of change and transformation is the impact of his perfect personality. Mogra (2010) describes Muhammad's personality as a teacher with the expression:

His noble character and sublime disposition played a critical role in his success as a model, guide, and teacher. His pleasant countenance, anger management, praise, and motivation absorbed his students. (p. 320)

An important feature of Muhammad is that he teaches through his behaviour and personality without contradiction between his statements and actions. This caused a deep impact on the students who appeared in the statement, 'For 
God's sake, I have not seen a better teacher than him. I swear: he did not scold, beat or berate me' (Al-Qushayri 1971).

The Prophet Muhammad is an example of a believer. Tawhid in Islamic teaching orientates action in two dimensions: for God based on the example of the Prophet Muhammad. Muslim educators should refer to the behaviour of the Prophet Muhammad as an educator because whatever the Prophet Muhammad was 'the channel of the revelation of the book which is considered by all Muslims to be the quintessential sum of all knowledge, both human and divine' (Nasr 1987). Consequently, the teacher not only learns to emulate but also has a deep personal commitment to faith and becomes a living example of virtue and piety that students can emulate without hesitation (Halstead 1995). In addition, Muslim teachers cannot escape the social problems faced by society, such as violence and intolerance. Muslim teachers can never be passive or indifferent to community problems (Tom 1981).

When the Prophet showed himself as a hilm, Muslim educators were obliged to be someone who was also a hilm. When the Prophet Muhammad had the core value of mercy (rahmah), Muslim educators should 'encompass themselves in compassionate virtues, using their intelligence to reflect on' signs 'of God in nature in order to foster the same spirit of caring and responsibility that will make them want to give to all God's creatures' (Armstrong 2012).

The basis of Muslim teaching theology, based on Al-Sira AlNabawiyya, is tawhid, patience, compassion and forgiveness. One of the teachers of Muslims who carried out this theology of non-violence was Abdul Ghafar Khan, a Muslim Indian fighter who, together with Gandhi, fought against British occupation by non-violence.

Ghaffar Khan is part of the Pashtuns who has the habit of fighting to solve problems. In the First War of Afghanistan, in 1838, Britain won the war, but in 1842 the Pashtuns took revenge, slaughtering 4500 British troops. The act of violence made the British and Pashtuns full of fear and hatred for each other, each of them believed that violence was the only right way [Easwaran 1999]. Ghafar Khan then got inspiration from Gandhi and was reinforced by the history of the Prophet Muhammad who continued to be patient when facing terror in Mecca (Easwaran 1990):

For a Muslim or Pashtun like myself, following a path of nonviolent life is not surprising. The road was not a new way of life, the road had been passed fourteen centuries ago by the Prophet all the time in Mecca, and since then, the road has been followed by those who want to leave the shackles of oppression. But we have forgotten the way. (p. 130)

Ghaffar Khan realised that the principles of Islam are 'work, faith, and love and without these, the name "Muslim" is sounding brass and tinkling cymbal' (Easwaran 1999). In 1929, Ghaffar Khan gathered Pashtuns youth and taught non-violent Islam. The young men became non-violent forces which he named as khudai khidmatgar [servants of God] who opposed the British occupation by the method of non-violence. Since then, many Pashtuns have been rooted strongly in a culture of violence, dropping their weapons and living non-violent lives against British occupation.

There are three main keys in the non-violent Islam for Khan, namely, tawhid, love and patience. About tawhid of love for others, Ghaffar Khan said (Easwaran 1999):

The Holy Prophet Mohammed came into this world and taught us: That man is a Muslim who never hurts anyone by word or deed, but who works for the benefit and happiness of God's creatures. Belief in God is to love one's fellowmen. (p. 55)

\section{Whilst about patience, Khan said (Easwaran 1999):}

I will give you weapons that the police or army cannot fight. The weapon is the weapon of the Prophet, but you don't understand it. The weapon is patience and truth. There is no power in this world that can fight it. (p. 149)

Patience is the weapon of the spreaders of the word, such as educators, 'if the spreaders of the word begin to mourn the mistreatment they receive, their sincerity in fighting for the faith is questionable' (Khan 1998). A Muslim educator teaches based on patience and teaches patience. From this principle of patience, a new generation will emerge facing the problem of Muslims by non-violence.

\section{Conclusion}

Islamic theology asserts that the life of the Prophet expresses practical instruction for everyone, whether Muslim or not. Indeed, the possibility of imitating the Prophet is the sine qua non of Islamic thought. More importantly here, Muhammad encouraged such mimesis in the context of religious teaching. When the reading of the history of the Prophet Muhammad results in the conclusion that violent behaviour is involved in the behaviour of the Prophet Muhammad, there is an example of violence as an important part of Islamic theology. How to interpret the history of the Prophet Muhammad's behaviour, thus, occupies an important position in encouraging the behaviour of the Muslims.

The history of the life of the Prophet Muhammad can be a source of Islamic learning without violence when approached with Girard's mimetic anthropology. Based on the reading of the mimetic anthropology of sira nabawiya, two conclusions were made. Firstly, all of Muhammad's life activities in the eyes of mimetic anthropology show a peaceful orientation and non-violence. The historical material is the same, but in the eyes of tawhid, there is a new reality that even the role activities in Medina (in which there are a number of wars) are also activities of love and non-violent struggle. Secondly, the entire life history of the Prophet Muhammad is based on the principles of tawhid, 
patience, love, forgiveness and respect for humanity which can be used as core values in the theology of Islamic education without violence.

\section{Acknowledgements Competing interests}

The author declares that they have no financial or personal relationships that may have inappropriately influenced them in writing this article.

\section{Author's contributions}

B.Q. is the sole author of this research article.

\section{Ethical considerations}

This article followed all ethical standards for a research without direct contact with human or animal subjects.

\section{Funding information}

This research received no specific grant from any funding agency in the public, commercial or not-for-profit sectors.

\section{Data availability}

Data sharing is not applicable to this article as no new data were created or analysed in this study.

\section{Disclaimer}

The views and opinions expressed in this article are those of the author and do not necessarily reflect the official policy or position of any affiliated agency of the author.

\section{References}

Afrianty, D., 2012, 'Islamic education and youth extremism in Indonesia', Journa of Policing, Intelligence and Counter Terrorism 7(2), 134-146. https://doi.org/10. 1080/18335330.2012.719095

Afsarudin, A., 2018, Tafsir Dekonstruksi Jihad \& Syahid, Khan as qu, Mizan, Bandung.

Aguilar Ramírez, J.D. \& De Beer, S., 2020, 'A practical theology of liberation: Mimetic theory, liberation theology and practical theology', HTS Teologiese Studies/ Theological Studies 76(2), a6165. https://doi.org/10.4102/hts.v76i2.6165

Ahmed, A.S., 2003, Rekonstruksi Sejarah Islam: Di Tengah Pluralitas Agama dan Peradaban, penerjemah, Fajar Pustaka Baru, Yogyakarta.

Al-Aqqad, A.M., 1942, 'Abqariyyat Muhammad [The Genius of Muhammad], Matba'at al-Istiqama, Cario.

Al-Ghazali, I., n.d., Ihya Ulum-id-Din, Sind Sagar Academy, Lahore.

Al-Ghazali, I., 1962, The book of knowledge, transl. N. A. Faris, Islamic Book Service, New Delhi.

Al-Qazwini, M.Y., 1993, Sunan Ibn-i-Majah, transl. M.T. Ansar, Kazi Publications, Lahore.

Al-Qushayri, M.H., 1971, Sahih Muslim, transl. A.H. Siddiqi, vol. 1, Dâr al-Manâr, Cairo.

Ali, K., 2014, The lives of Muhammad, Harvard University Press, Cambridge, MA.

Anderson, B., 1991, Imagined communities: Reflections on the origin and spread of nationalism, Verso, London.

Armstrong, K., 2011, Muhammad Sang Nabi: Sebuah Biografi Kritis, transl. Risalah Gusti, Surabaya.

Armstrong, K., 2012, Compassion 12 Langkah Menuju Hidup Berbelas Kasih, Mizan, Bandung.

Atay, R., 2007, 'Reviving the Suffa tradition', in Ihsan Yilmaz., et all (ed.), Muslim world in transition: Contributions of the Gulen Movement International Conference Proceeding, pp. 450-472, Leeds Metropolitan University Press, London.

Azami, M.M., 1992, Studies in Hadith methodology and literature, American Trust Publications, Indianapolis.
Azca, M.N., 2013, 'Yang Muda, Yang Radikal: Refleksi Sosiologis Terhadap Fenomena Radikalisme Kaum Muda Muslim di Indonesia Pasca Orde Baru', Maarif: Arus Pemikiran Islam dan Sosial 8(1), pp. 14-44.

Baidhawy, Z., 2007, 'Building harmony and peace through multiculturalist theologybased religious education: An alternative for contemporary Indonesia', British Journal of Religious Education 29(1), 15-30. https://doi.org/10.1080/0141 6200601037478

Burhanuddin, N., 2016, 'Akar dan Motif Fundamentalisme Islam: Reformulasi Tipologi Fundamentalisme dan Prospeknya di Indonesia', Wawasan: Jurnal Ilmiah Agama dan Sosial Budaya 1(2), 199-210. https://doi.org/10.15575/jw.v1i2.831

Burns, J.P., 1996, War and its discontents: Pacifism and Quietism in the Abrahamic tradition, Georgetown University Press, Washington, DC.

Chapman, A.R., 2007, Teaching the violent past: History education and reconciliation, Rowman \& Littlefi, Lanham, MD.

Considine, C., 2016, 'Religious pluralism and civic rights in a "Muslim nation": An analysis of Prophet Muhammad's covenants with Christians', Religions 7(2), 15. https://doi.org/10.3390/rel7020015

Considine, C., 2018, Muhammad Nabi CInta, Catatan Seorang Nasrani tentang Rasulullah saw, Noura, Jakarta.

Darmalaksana, W., Busro, Qodim, H. \& Riyani, I., 1990, Violent and nonviolent struggle in Arab history, Arab Nonvi, Lynne Rienner, Boulder, CO.

Davies, L., 2004, Education and conflict: Complexity and chaos, Routledge and Falmer London.

Departemen Agama RI, 2004, Pedoman Khusus Sejarah Kebudayaan Islam, Depag RI, Jakarta.

Departemen Agama RI, 2015, Al-Quran an terjemahan, Depag RI, Jakarta.

Easwaran, E., 1984, A man to match his mountains: Badshah Khan, nonviolent soldier of Islam, Nilgiri Press, Petaluma, CA.

Easwaran, E., 1999, Nonviolent soldier of Islam, Nilgiri Press, Tomales, CA.

Emerson, S., 2003, American Jihad: The terrorist living among us, Free Press, New York, NY.

Ericksen, A., 2009, The universal truths of Islam and mimetic anthropology: The Tawhid of God and the Tawhid of being human, paper colloquium on violence and religion (10th July 2009), St Mary's University College, Strawberry Hill and Heythrop College, University of London - London, England.

Fuad, M., 2020, 'International publications on radicalism and terrorism in Indonesia: A bibliometric assessment', Wawasan: Jurnal Ilmiah Agama dan Sosial Budaya 5(1), 96-107. https://doi.org/10.15575/jw.v5i1.8028

Gade, A.M., 2010, Religious biography of the Prophet Muhammad in twenty-firstcentury Indonesia, Cambridge University Press, New York, NY.

Ghiloni, A.J., 2016, 'Muhammad, education, and finitude', Religious Education 111(3), 288-306.

Ghuddah, A.F.A., 2003, Prophet Muhammad the teacher and his teaching methodologies, transl. Millat Book Centre, New Delhi.

Girard, R., 1986, The scapegoat, The John Hopkins University Press, Baltimore, MD.

Girard, R., 2001, I see satan fall like lightning, Maryknoll, Orbis Books, New York, NY.

Gulen, M.F., 2010, Muhammad: The messenger of God, transl. A. U“ nal, Tughra Books, Clifton, NJ.

Gulick, R.L., 1953, Muhammad the educator, Institute of Islamic Culture, Lahore.

Habeck, M., 2006, Knowing the enemy: Jihadist ideology and the war on terror, p. 3 , Yale University Press, New Haven, CT.

Halstead, M., 1995, 'Towards a unified view of Islamic education', Islam and Christian-Muslim Relations 6(1), 25-43. https://doi.org/10.1080/0959641950 8721040

Hamidullah, M., 1939, 'Educational system in the time of the Prophet', Islamic Culture 13(1), 48-59. https://doi.org/10.2307/2262236

Haykal, M.H., 1976, The life of Muhammad (I. al-Faruqi, Trans.), American Trust Publications, Plainfield, IN.

Haykal, M.H., 1989, The life of Muhammad, transI. I.R. Al-Faruqi, Darul-Ishaat, Karachi.

Hisham, I., 2002, Sirat Ibn Hisham: Biography of the Prophet (SAW), transl. A.-S.M. Harun, Al-Falah Foundation, Cairo.

Ishaq, M.I., 1987, The life of Muhammad: A translation of Ibn Ishaq's Sirat Rasul Allah, transl. Oxford University Press, Oxford.

Izutsu, T., 2002, Ethico religious concept on the Quran, Montreal.

John Andrew Morrow, 2013, The Covenants of the Prophet Muhammad with the Christians of the World, Angelico Press/Sophia Perennis, Kettering.

Juergensmeyer, M., 2003, Terror in the mind of God: The global rise of religious violence, University of California Press, Oakland.

Karim, C.D., 1998, Nurturing an Islamic peace discourse, Centre for American University, Washington, DC.

Kartodirdjo, S., 1990, Sejarah Indonesia modern, Gama Press, Yogyakarta.

Kaymakcan, R., 2007, Teaching for tolerance in Muslim majority societies, R. Kaymakc, Istanbul.

Khan, W., 1998, Muhammad a Prophet for all humanity, Goodword Book, New Delhi.

Khan, W., 2002, True Jihad the concept of peace, tolerance, and non violence, Goodword Books, New Delhi. 
Kippenberg, H., 2011, Violence as worship: Religious wars in the age of globalisation, transl. Stanford University Press, Stanford, CA.

Kuntowijoyo, L., 1991, Paradigma Islam: Interpretasi untuk Aksi, Mizan, Bandung.

Kuntowijoyo, 1994, Metodologi Sejarah, Tiara Wacana, Yogyakarta.

Lings, M., 1983, Muhammad: His life based on the earliest sources, The Islamic Texts Society, Cambridge.

Mogra, I., 2010, 'Teachers and teaching: A contemporary Muslim understanding', Religious Education 105(3), 317-329. https://doi.org/10.1080/00344081003772089

Mohanty, S.K. \& Mahanty, J.N., 2010, 'Military-Madrasa-Mullah complex: Promoting Jihadist Islam in Pakistan', India Quarterly 66(2), 133-149. https://doi.org/ 10.1177/097492841006600201

Muhammad, W.A. \& Pribadi, K.K., 2013, 'Anak Muda, Radikalisme, dan Budaya Populer', Jurnal Maarif 8(1), 132-153.

Muller-Fahrenholz, G., 1990, 'Is forgivness in politics possible?: 10 theses', pape presented in the 13th general conference of the International Peace Research Association, Groningen.

Nasr, S.H., 1987, Science and civilization in Islam, 2nd edn., Islamic Text Society, Cambridge.

Nimer, M.A., 2003, Nonviolence and peace building in Islam: Theory and practice, University of Florida Press, Gainesville, FL.

Nurwanto, N. \& Cusack, C., 2017, 'Correction to: Addressing multicultural societies: Lessons from religious education curriculum policy in Indonesia and England", Journal of Religious Education 65(95), 157-168. https://doi.org/10.1007/s40839$017-0045-5$

Omar, I.A., 1999, 'Islam and the other: The ideal vision of Mawlana Wahiduddin Khan', Journal of Ecumenical Studies 36(3/4), 423-439.

Pal, A., 2017, 'A religion of peace? Islam and its heritage of nonviolence', Diogenes 61(3), 71-81. https://doi.org/10.1177/0392192116666469

PPIM UIN Syarif Hidayatullah Jakarta, 2018, Pelita yang Meredup: Potret Keberagamaan Guru Indonesia, Jakarta.

Purwakania Hasan, A.B. \& Suwarni, E., 2012, 'Policies and practices for promoting multicultural awareness of indigenous early childhood education in Indonesia', International Journal of Child Care and Education Policy 6(1), 63-94. https://doi. International Journal of Child Care
org/10.1007/2288-6729-6-1-63

Raihani, R., 2011, 'A whole-school approach: A proposal for education for tolerance in Indonesia', Theory and Research in Education 9(1), 23-39.

Rangga Eka Saputra, 2017, Api dalam Sekam: Keberagamaan gen Z: Survei Nasiona tentang Sikap Keberagamaan di Sekolah dan Universitas di Indonesia, PPIM UIN Syarif Hidayatullah Jakarta.
Ramadan, T., 2005, Western Muslims and the future of Islam, Oxford University Press, Oxford.

Ramadan, T., 2007, The messenger: The meanings of the life of Muhammad, Penguin, London.

Ramadan, T., 2008, Radical reform: Islamic ethics and liberation, Oxford University Press, Oxford.

Ramadan, T., 2009, In the footsteps of the prophet, Oxford University Press, Oxford.

Sachedina, A.A., 2000, The Islamic roots of democratic pluralism, Oxford University Press, New York, NY.

Samudra, I., 2005, Aku Melawan Teroris, Aljajera, Solo.

Saqeb, G. N., 1996, 'Teacher training in Islam: Its importance and practicalities', Issues in Islamic education, pp. 28-37, The Muslim Education Trust, London.

Satha-Anand, C., 2015, 'Barangsiapa Memelihara Kehidupan' Esai-esai tentang Nirkekerasan dan Kewajiban Islam, Paramadina, Jakarta.

Schwarzmantel, J., 2011, Democracy and political violence, Edinburgh University Press, Edinburgh.

Smith, A. \& Vaux, T., 2003, Education, conflict and international development, Department of International Development, London.

Tibawi, A.L., 1954, 'Muslim education in the golden age of the caliphate,' Islamic Culture 38, 418-438.

Tom, B.E., 1981, 'Education and society', in M.W. Khan (ed.), Education and society in the Muslim world, pp. 28-44, Hodder and Stoughton, London.

Totah, K.A., 1926, The contribution of the Arabs to education, Columbia University, New York, NY.

Untung, M.S., 2005, Muhammad Sang Pendidik [Muhammad the noble teacher/great educator], Pustaka Rizki Putra, Semarang.

Wahiduddin Khan, M., 1998, 'Nonviolence and Islam', paper presented in the Forum on Islam and Peace in the twenty-first century (February 6-7, 1998), 5, American University, Washington, DC.

Wan Daud, W.M.N., 1989, The concept of knowledge in Islam and its implications for education in a developing country, Mansell, London.

Waqidi, A., 2012, Kitab Al Maghazi Muhammad Sumber Sejarah Paling Tua Tentang Kisah Hidup Rasulullah, Zaytuna, Jakarta.

Watt, W.M., 1990, Kejayaan Islam: Kajian Kritis dari Tokoh Orientalis, translator: Hartono Hadikosuma) translated, Tiara Wacana, Yogyakarta.

Watt, W.M., 2012, Ahl Al-suffa in encyclopaedia of Islam, 2nd edn., Brill, Leiden.

Williams, J., 1996, The Girard reader, The Crossroads Publishing Company, New York, NY. 